\title{
Pediatric fibromatosis involving mandible: case reportand a five-year post-operative follow-up
}

\author{
Fibromatose pediátrica em mandíbula: \\ relato de caso e avaliação pós-operatória de cinco anos
}

Vilson Lacerda Brasileiro Junior ${ }^{1}$; Laura Priscila Barboza de Carvalho²; Cláudia Roberta Leite Vieira de Figueiredo 3 ; Marcos Antônio Farias de Paiva ${ }^{4}$

\begin{abstract}
Extra-abdominal fibromatosis is a benign fibrous neoplasm of locally aggressive behavior. Surgical excision with a wide margin is the treatment of choice. The aim of the present work is to report the case of fibromatosis in an 11-year-old melanodermic patient, who showed swelling in the area of the right mandible. Conservative surgery was performed based on the initial histopathological diagnosis of benign lesion suggestive of neural origin. The new anatomopathological examination of the surgical specimen was compatible with fibromatosis. The patient is still under periodic observation as part of the five-year surgical follow-up, showing no signs of recurrence.
\end{abstract}

Key words: desmoplastic fibroma; extra-abdominal fibromatosis; desmoid tumor.

\section{INTRODUCTION}

Extra-abdominal fibromatosis (desmoid tumor) is a benign fibrous neoplasm that arises from musculoaponeurotic structures with locally aggressive behavior ${ }^{(12,17)}$. Fibromatoses are classified as superficial and deep. The deep type is aggressive, grows quickly and penetrates extensively, whether in a diffuse, multifocal way or locally, simulating malignancy ${ }^{(2,9,10)}$. Head and neck lesions are considered deep fibromatoses of the extra-abdominal type ${ }^{(14)}$.

Although extra-abdominal fibromatosis may affect any age group (newborn to elderly), it is an illness that predominantly affects children and young adults. It is frequently called aggressive juvenile fibromatosis ${ }^{(7,11)}$. The most common affected places are the shoulder and trunk, with approximately $10 \%$ of cases occurring in the soft tissue of head and neck. Infantile extraabdominal fibromatosis occurs more in females than in males at a ratio of $3: 1^{(2)}$.

Its pathogenesis is unknown, but it is believed that hereditary factors and hormones play a role in the emergence of the lesion.
Some studies associate tumor growth with estrogen level, since there is a spontaneous regression found during menarche and menopause ${ }^{(12,16)}$.

Clinically, extra-abdominal fibromatosis manifests as a painless, firm mass that grows rapidly and fixes to bone and soft tissue $^{(2)}$. Invasion of bone or skin is not very common ${ }^{(11)}$.

Histologically, the tumor consists of a proliferation of uniform-appearing, spindle-shaped fibroblasts, separated by dense collagen masses. The lesion has ill-defined proportions and tends to interlace with muscle fiber, hindering its surgical excision ${ }^{(12)}$. Although extra-abdominal fibromatosis does not generally metastasize or suffer sarcomatous degeneration, recurrence rate is high.

Treatment of head and neck fibromatosis is complete surgical excision, in which recurrence is high when negative surgical margins are not achieved ${ }^{(2,13)}$.

Here is a case of extra-abdominal fibromatosis involving an 11-year-old patient.

First submission on 21/07/12; last submission on 22/04/13; accepted for publication on 09/05/13; published on 20/06/13

1. Attending doctorate in Oral Pathology at Universidade Federal do Rio Grande do Norte (UFRN); assistant professor of Odontology at Centro Universitário de João Pessoa (UNIPE).

2. Master's in Oral Diagnosis by Universidade Federal da Paraíba (UFPB); dental surgeon at UFPB.

3. Doctor in Oral Pathology by Universidade de São Paulo (USP); associate professor of General Pathology at UFPB.

4. Doctor in Stomatology by UFPB; professor of Surgery I at UFPB. 


\section{CASE REPORT}

An 11-year-old female, melanodermic patient came to the Oral and Maxillofacial Surgery and Trauma Unit of a municipal hospital with symptoms of pain and facial asymmetry. In the anamnesis, the patient's mother said that she did not know when the lesion had begun, but did say that swelling in the mandibular region of the right side was perceptible in the preceding two months, when the patient began to complain about sensitivity in the area. While performing the extraoral physical exam, a swelling of the lower third of the right side of the face was noticed. When performing the intraoral physical examination, it was discovered that the swelling extended from element 47 to the right mandibular ramus. Imaging examinations were requested. The panoramic radiograph showed a lytic lesion of infiltrative growth, with extensive destruction of the underlying mandibular bone area, causing upper displacement of tooth 48 (Figure 1). The computerized tomography showed the presence of a potentially expansive hypoattenuating lesion in the right mandibular ramus with a thinning of cortical bone. An internal and external expansion of the cortical bones could also be noticed, extending from the body to the middle third of the mandibular ramus (Figure 2). An incisional biopsy was performed and its diagnosis was suggestive of a benign lesion of neural origin. Based on the anatomo-pathological result, conservative surgery was performed. A new histological examination of the surgical specimen, in association with immunohistological evaluation, was compatible with fibromatosis. Five years after surgery, there was complete local bone repair, with no recurrence (Figure 3).

\section{DISCUSSION}

The term fibromatosis covers a range of rare benign soft tissue lesions that are locally invasive and may occur in various parts of the body. It is estimated that approximately $12 \%-15 \%$ of these lesions occur in the head and neck region and affect mostly

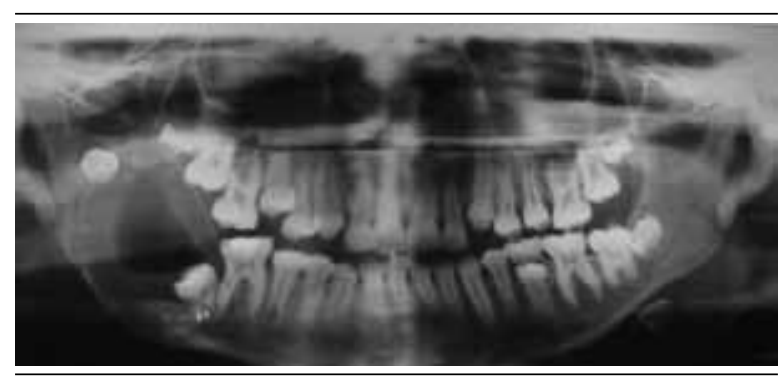

FIGURE 1 - Preoperative panoramic radiograph of the patient showed expansive lytic lesion located in the posterior mandible region

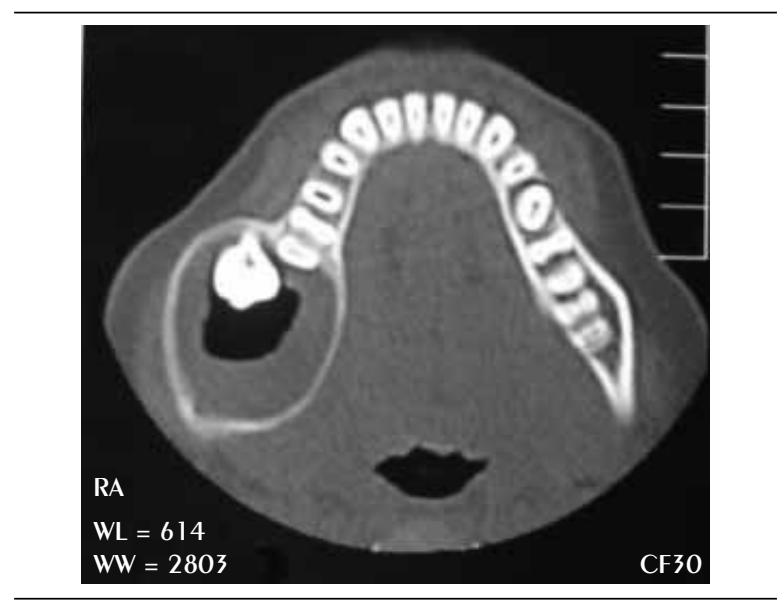

FIGURE 2 - Preoperative computed tomography showed the presence of a potentially expansive hypoattenuating lesion in the right mandibular ramus with a thinning of cortical bone

RA: right angle; WL: window level; WW: window width; CF: convolution filter.

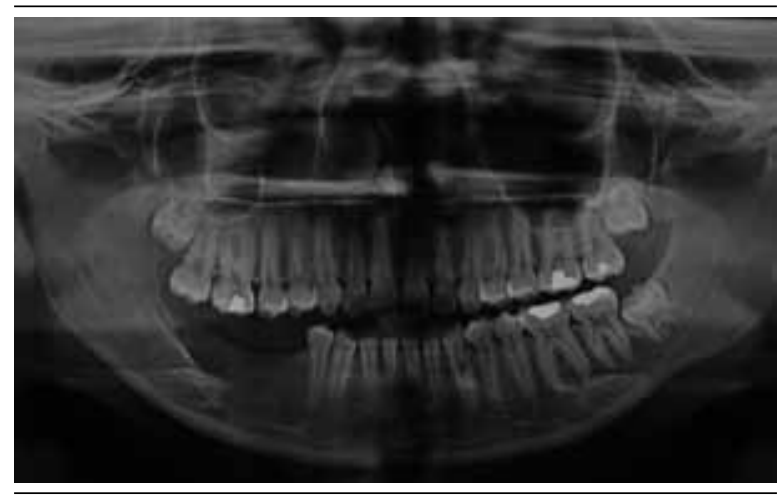

FIGURE 3 - Panoramic radiograph five years after surgery: observed complete repair of local bone with no recurrence

children and young adults. They are classified as extra-abdominal fibromatosis ${ }^{(14,15)}$. However, there are other authors that claim that $34 \%$ of all cases of fibromatosis occur in the head and neck region $^{(1)}$.

As far as the growth of this disease is concerned, most studies $^{(2,9,10-12,16)}$ say that the lesion is of rapid growth and its differential diagnosis should include desmoplastic fibroma, nodular fasciitis, fibrosarcoma and neurofibroma ${ }^{(6)}$.

Due to histopathological likenesses, some authors believe that the desmoplastic fibroma is the osseous counterpart of fibromatosis. Furthermore, the desmoplastic fibroma may be distinguished from the nodular fasciitis by having a pattern of more infiltrative growth, larger production of collagen, less cellularity and less mitotic figures. In its turn, fibromatosis is distinct from fibrosarcoma due to the fact that malignant tumors present a herringbone pattern, pleomorphic and hyperchromatic nuclei as well as abundant and atypical mitosis ${ }^{(7,8)}$. 
Histologically, fibromatosis presents areas with many cells, alternating with areas with few, densely collagenized cells. Most cells correspond to mature fibroblasts with large uniform nuclei. In general, tumor cells are not atypical, being negative for $\$ 100$ protein on the immunohistochemical test, which distinguishes them from neoplastic cells of neural origin ${ }^{(2,3,11,16)}$.

According to Hauben et al. ${ }^{(4)}$, the presence of genetic mutations in the lesions may lead to an intranuclear accumulation of betacatenin, resulting in an expressive nuclear immunoreactivity for this marker. However, in the study of Sharma et al. ${ }^{(12)}$, the authors affirm that beta-catenin is not a precise marker for the diagnosis of infantile fibromatosis.

In the present case, the histological examination of the surgical specimen revealed bundles of fibroblasts of large nuclei, ovoid or triangular, intertwined with large quantities of collagen (Figure 4). Highly cellular areas were intertwined with almost acellular, densely collagenized regions. There was no atypia or mitosis. The immunohistochemical examination showed a negative result for the $\$ 100$ protein and positive for Vimentin (Figure 5), hence the appraisal report indicated fibromatosis.

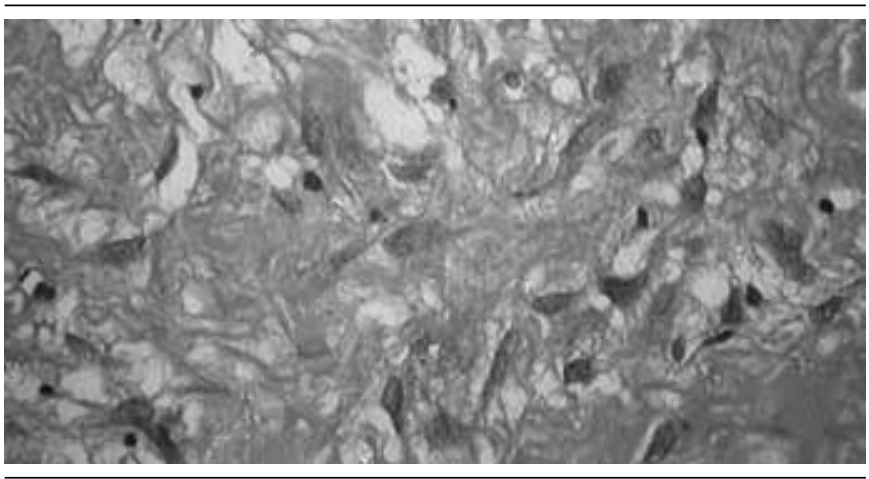

FIGURE 4 - The histological examination of the surgical piece revealed bundles of fibroblasts of large, oval or triangular nucleus, interspersed with large amounts of collagen (HE, 400×)

HE: hematoxylin and eosin

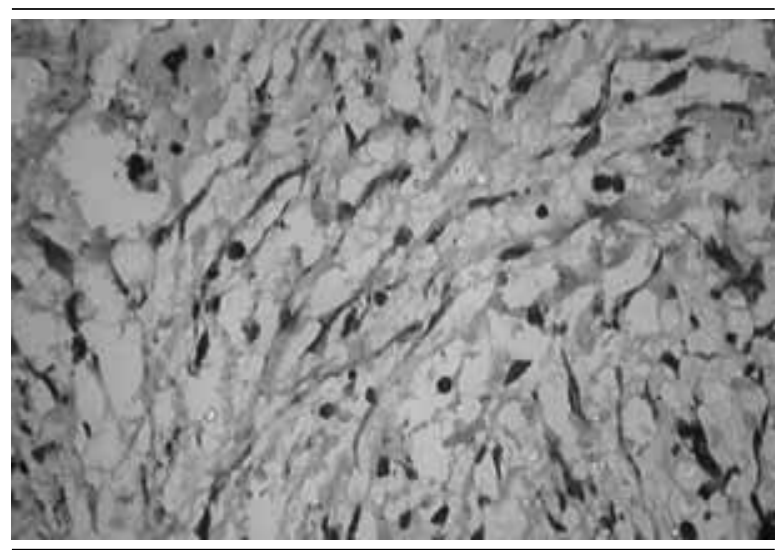

FIGURE 5 - The neoplastic fibroblasts were positive for vimentin (VIMENTIN, $400 \times)$

Although there is still a lot of controversy and discussion in the literature, most authors agree that the treatment of choice should be the surgical excision of the lesion ${ }^{(2,5,9)}$. The extension of surgery varies considerably and depends on the size of the lesion, but excision with a wide surgical margin may be recommended, thus minimizing the risk of local recurrence ${ }^{(2,11,16)}$. However, this option is difficult in patients with tumors in the head and neck region due to the anatomical complexity and the proximity of vital structures ${ }^{(14)}$.

When complete resection of lesions does not occur, they have a local recurrence rate that varies between $50 \%-70 \%$ of cases $^{(3,13)}$. In children, surgical treatment of extra-abdominal fibromatosis is even more complicated because of the potential risk of functional incapacity ${ }^{(11)}$. In the reported case, a less invasive treatment was chosen based on the initial diagnosis. As the final diagnosis of the surgical specimen was compatible with fibromatosis, careful follow-up has been undertaken. It is worth mentioning that in five years a complete repair of the affected bone area has been achieved, with no signs of recurrence to date.

\section{RESUMO}

Fibromatose extra-abdominal é uma neoplasia fibrosa benigna, caracterizada por comportamento agressivo local. Geralmente, o tratamento de escolba consiste na excisão cirúrgica com ampla margem de segurança. O objetivo deste trabalho é relatar um caso de fibromatose em uma paciente de 11 anos, melanoderma, que apresenta aumento de volume na mandíbula do lado direito. A partir do diagnóstico bistopatológico inicial sugestivo de lesão benigna de origem neural, foi realizado tratamento cirúrgico conservador. Um novo exame anatomopatológico da peça cirúrgica foi compativel com fibromatose. A paciente encontra-se sob controle periódico de cinco anos da cirurgia, não bavendo recorrência clínica da lesão.

Unitermos: fibroma desmoplásico; fibromatose extra-abdominal; tumor desmoide. 


\section{REFERENCES}

1. BHASKAR, A. R. et al. Large myofascial fibromatosis involving the shoulder girdle.J Postgrad Med, v. 40, n. 4, p. 225-7, 1994.

2. DE RIU, G. et al. Complications of mandibular reconstruction in childhood: report of a case of juvenile aggressive fibromatosis J Craniomaxillofac Surg, v. 34, n. 3, p. 168-72, 2006.

3. GARCÍA, R. G. et al. Fibromatosis of the tongue: a case report. Oral Surg Oral Med Oral Pathol Oral Radiol Endod, v. 100, n. E31-4, 2005.

4. HAUBEN, E. L. et al. Desmoplastic fibroma of bone: animmunohistochemicalstudyincludingb-cateninexpressionandmutationalanalysisforbcatenin. Hum Pathol, v. 36, n. 9, p. 1025-30, 2005.

5. KROKIDIS, M. et al. Infantile fibromatosis of the mandible: a case report. Dentomaxillofacial Radiol, v. 37, p. 167-70, 2008.

6. KRUSE, A. L. et al. Aggressive fibromatosis of the head and neck: a new classification based on a literature review over 40 years. Oral Maxillofac Surg, v. 14, p. 227-32, 2010.

7. NEVILLE, B. W. et al. Patologia oral e maxilofacial. 3. ed. Rio de Janeiro: Elsevie, 2009.

8. REGEZI, J. A. et al. Patologia oral: correlações clinicopatológicas. 5. ed. Rio de Janeiro: Elsevier, 2008.
9. RUPARELIA, M. S.; DHARIWAL, D. K. Infantile fibromatosis: a case report and review of the literature. Br J Oral Maxillofac Surg, 2010.

10. SATO, K. et al. Desmoid-type infantile fibromatosis in the mandible: a case report. Am J Otolaryngol, v. 21, n. 3, p. 207-12, 2000.

11. SEPER, L. et al. Aggressive fibromatosis involving the mandible-case report and review of the literature. Oral Surg Oral Med Oral Pathol Oral Radiol Endod, v. 99, n. 1, p. 30-8, 2005.

12. SHARMA, A. et al. Pediatric aggressive fibromatosis of the head and neck: a 20-year retrospective review.J Pediatric Surg, v. 43, n. 9, p. 1569604, 2008.

13. SHUKER, S. T.; JABRO, M. H. Case report of submandibular aggressive fibromatosis in a16-month-old infant with 8-year postsurgical follow-up. J Oral Maxillofac Surg, v. 61, p. 951-4, 2003.

14. SIEGEL, N. S.; BRADFORD, C. R. Fibromatosis of the head and neck: a challenging lesion. Otolaryngol Head Neck Surg, v. 123, p. 269-75, 2000.

15. SUN, G. et al. Treatment of aggressive fibromatosis of the head and neck. J Craniofac Surg, v. 21, p. 1831-3, 2010.

16. TOSTEVIN, P. M. J. et al. Six cases of fibromatosis of the head and neck in children. Int J Pediatr Otorbinolaryngol, v. 53, p. 235-44, 2000.

17. WATZINGER, F. et al. Aggressive fibromatosis of the mandible: a case report. Int J Oral Maxillofac Surg, v. 34, n. 2, p. 211-3, 2005.

\section{MAILING ADDRESS}

Vilson Lacerda Brasileiro Junior

Avenida Epitácio Pessoa, 4.595, apto 401 A; Tambaú; CEP: 58039-000; João Pessoa-PB, Brazil; e-mail: vilsonjnr@hotmail.com. 